\title{
Bird assemblage mist-netted in an Atlantic Forest area: a comparison between vertically-mobile and ground-level nets
}

\author{
Vecchi, MB. ${ }^{a *}$ and Alves, $M A S .^{a}$ \\ aDepartamento de Ecologia, Instituto de Biologia Roberto Alcantara Gomes, Universidade do Estado do \\ Rio de Janeiro - UERJ, Rua São Francisco Xavier, 524, CEP 20550-011, Rio de Janeiro, RJ, Brazil \\ *e-mail: mbvecchi@yahoo.com
}

Received: January 17, 2014 - Accepted: March 20, 2014 - Distributed: August 31, 2015

(With 2 figures)

\begin{abstract}
Mist nets may be opened at different heights in the forest, but they are seldom used over $3 \mathrm{~m}$ above the ground. We used two different methods to compare species richness, composition, and relative abundance and trophic structure of the bird assemblage at Ilha Grande (with a 290 birds standardization): conventional ground-level nets (0-2.4 m height range) and elevated nets (0-17 m) with an adjustable-height system (modified from Humphrey et al., 1968) that we call vertically-mobile nets. There were significant differences in capture frequencies between methods for about $20 \%$ of the species (Chi-squared test, $P<0.05$ ), and the two methods caught different assemblages. Ground-level nets recorded less species, and they comparatively overestimated mainly Suboscine insectivores and underestimated frugivores and nectarivores. Different sampling methods used at the same location may result in very different diagnoses of the avifauna present, both qualitatively and quantitatively. We encourage studies involving mist net sampling to include the upper strata to more accurately represent the avifauna in Atlantic Forest.
\end{abstract}

Keywords: canopy, high nets, mist net sampling, trophic structure, vertical stratification.

\section{Assembleia de aves capturadas em redes de neblina em uma área de Mata Atlântica: uma comparação entre redes verticalmente móveis e no nível do solo}

\begin{abstract}
Resumo
Redes-de-neblina podem ser abertas a diferentes alturas na floresta, mas raramente são usadas acima de $3 \mathrm{~m}$ do chão. Usamos dois diferentes métodos para comparar riqueza, abundância relativa de espécies e estrutura trófica da assembleia de aves da Ilha Grande (com a padronização de 290 indivíduos): redes convencionais no nível do solo (0-2,4 m de altura) e redes bandeira (0-17 m) com um sistema de ajuste de altura (modificado de Humphrey et al., 1968) que denominamos redes verticalmente móveis. Houve diferenças significativas nas frequências de capturas entre os métodos em cerca de $20 \%$ das espécies (teste Qui-quadrado, $P<0,05$ ), e os dois métodos capturaram diferentes assembleias. Redes de neblina no nível do solo registraram menos espécies, e comparativamente superestimaram principalmente espécies insetívoras de Suboscine, e subestimaram frugívoras e nectarívoras. Métodos diferentes de amostragem usados em uma mesma localidade podem resultar em uma diagnose bem distinta da avifauna presente, tanto qualitativa como quantitativamente. Recomendamos que estudos envolvendo amostragens com redes-de-neblina incluam os estratos superiores para representar mais acuradamente a avifauna na Mata Atlântica.
\end{abstract}

Palavras-chave: dossel, redes-bandeira, amostragem com redes-de-neblina, estrutura trófica, estratificação vertical.

\section{Introduction}

Mist nets have been used for decades in ornithological studies (Low, 1957), although the use of other bird sampling methods to estimate abundance, such as spot-mapping and transects, has been widespread in the Tropics (Terborgh et al., 1990). However, mist nets are still the main tool used in studies based on capture of terrestrial birds (Karr, 1981), and they are an important additional sampling method in bird community studies (Whitman, 2004; Arizaga et al.,
2011) and inventories (Wang and Finch, 2002). Although mist nets may be opened at different heights in the forest (Humphrey et al., 1968), they are seldom used over $3 \mathrm{~m}$ above ground level, and neglect a number of other species associated with the upper strata of the forest such as medium and large-sized birds (Vecchi, 2007; Wang and Finch, 2002). Most studies on canopy birds are restricted to observations at ground level (Orians, 1969; Pearson, 1971). Thus, the 
detection of these birds is usually compromised, which leads to an underestimation of richness and abundance of species associated with higher forest strata (Walther, 2003; Derlindati and Caziani, 2005; Anderson, 2009). Studies that directly access canopy birds generally involve observations from towers placed at the height of emergent trees (Greenberg, 1981; Loiselle, 1988; Naka, 2004; Anderson and Naka, 2011), platforms (Bouricius et al., 2002; Peña-Foxon and Díaz, 2012) and walkways, where mist nets can also be employed (Rahman, 2002), or cranes with more sophisticated technology (Shaw, 2002).

Data from mist net captures are clearly biased, with differences in the capture success among bird species (MacArthur and MacArthur, 1974). However, captures allow the precise identification of bird species, which differs from inventories based only on observation, where identification is occasionally only possible at taxonomical levels higher than species, especially in the case of cryptic birds. Moreover, mist nets allow researchers to mark birds individually, which allow studies that estimate home ranges, survivorship and population sizes and trends (Dunn and Ralph, 2004). However, using only mist-netting data to estimate population sizes or home-range data also faces sampling issues. Additionally, capturing and manipulating birds provides valuable information for studies that involve morphometry, molt schedule, fecal analysis, endo and ectoparasitism, migration and genetics.

One of the main problems that studies estimating bird population sizes in tropical regions faces is that most species do not occur in the understory (Pearson, 1975) and often are not captured and banded. Different techniques have been developed for using mist nets above the ground level (Greenlaw and Swinebroad, 1967; Humphrey et al., 1968; Whitaker, 1972; Dejonghe and Cornuet, 1983; Munn, 1991; Stokes et al., 2000), and they have also been used in bat studies (Bernard, 2001). With a little technical innovation, it is possible to reliably sample structurally complex habitats, which provides vital information on the vertical distribution of birds (Ramachandran and Ganesh, 2013). However, these techniques are seldom used because they are usually more complex, expensive and laborious than conventional understory mist-netting techniques (Ralph et al., 1993). Although more contemporary studies use nets to gather population demographic data, many studies also use mist nets to characterize forest bird species assemblages. Therefore, it is important to know the qualitative and quantitative shortcomings of data coming from mist nets restricted to the understory, which is the most common method to capture terrestrial birds. As there is a number of bird species associated with the upper strata of the forest, it is desirable for mist net studies not to be limited to the understory. The present study compares capture data of the bird assemblage in an Atlantic forest area obtained in mist nets using two different methods: conventional understory nets (reaching a low height above the ground) and vertically-mobile nets (sampling different heights from the ground to the canopy). We evaluated the differences in composition, relative species abundance and trophic structure using the two methods. We will discuss a detailed approach on bird assemblage stratification elsewhere. Additionally, we describe the modifications we included that enhanced the set up and maintenance of the vertically-mobile mist net system and bird capture in the higher forest strata.

\section{Material and Methods}

\subsection{Study area}

The study took place at Ilha Grande, a 19,300 ha continental island located in Angra dos Reis, southern Rio de Janeiro state. Annual rainfall in the area is around $1700 \mathrm{~mm}$ and mean annual temperature is about $23^{\circ} \mathrm{C}$ (Alho et al., 2002). A total of 222 species have been recorded on the island (Alves and Vecchi, 2009). We used a 5-ha grid at an elevation of about $240 \mathrm{~m}\left(23^{\circ} 10^{\prime} 30^{\prime}\right.$ S, $44^{\circ} 12^{\prime} 10^{\prime}$ 'W) covered by low disturbed Atlantic Forest, where our team has conducted long term studies on bird ecology since the 1990's (Alves, 2001). The canopy of the study area averages $23 \mathrm{~m}( \pm 5.8)$ and varies from $10-35 \mathrm{~m}$, although some emergent trees reach $40 \mathrm{~m}$ in height (M. B. Vecchi, unpubl. data). As in most mature forests, the understory is relatively sparse and penetrable.

\subsection{Vertically-mobile (VM) nets}

In order to capture birds at different heights, we followed Humphrey et al. (1968), supporting the nets by a system of ropes and pulleys, with some adjustments described in Appendix 1. We used mist nets of $12.0 \times 2.4 \mathrm{~m}$ (four shelves, $36 \mathrm{~mm}$ mesh) set up in 12 sites, suspended at seven heights between $0-17 \mathrm{~m}$ above the ground: 1 (0-2.4 m); 2 (2.4-4.8 m); 3 (4.8-7.2 m); 4 (7.2-9.6 m); 5 (9.6-12 m); 6 (12-14.6 m); 7 (14.6-16.8 m). Due to practical reasons, we used a maximum of two VM nets in the same rope system per sampling site, and the nets at level 1 (0-2.4 m) were traditional ground level ones (supported by aluminum poles), which enable a better opening and stretching of the nets at that height. The level 1 nets were set in the same position of the rope systems.

The nets were opened immediately after dawn, sampling daily 8-11 hours, and were checked at $1 \mathrm{~h}$ intervals. The captures were carried out between July and September 2005, and summed 419 net-hours at each one of the seven sampled levels (total 2931 net-hours).

\subsection{Ground-level (GL) nets}

In order to obtain capture data with the conventional method (0-2.4 m), we used our primary data from a long-term project developed in the same study grid using nets with the same specifications as above, but which included monthly samplings of 140 net-hours (10 nets open just after dawn for 7 hours, during two consecutive days). In this long-term study, we sampled three trails alternately for a total of 30 net sites. According to our experience, the capture efficiency (number of individuals/net-hours) of canopy-subcanopy nets is much lower (about one third) than that of understory nets. However, our interest in this study was to show and compare the bird species caught 
in nets, and not species catch rates (individuals/net-hour). Therefore, for comparison with VM nets, we standardized the capture effort at 290 individuals (recaptures excluded), since this was the total number of captures obtained in VM nets. To minimize the effect of seasonality on the sampled avifauna, we did not use data obtained between October and March (reproductive season) from the GL nets. Therefore, to reach 290 captured birds, we used data sets from Jul-Sep/2004, Apr-Sep/2005 and Jul-Sep/2006. Our total sampling effort (net-h) was approximately 1,65 net-h of GL nets, and 2,900 net-h of VM nets.

\subsection{Banding and categorization of birds}

After identification, each bird was individually marked with a numbered metallic band (CEMAVE/ICMBio) and then released. We categorized the species into trophic guilds according to their predominant diets, mainly based on Moojen et al. (1941), Schubart et al. (1965), Durães and Marini (2005), Naka (2004), Sick (1997), Lopes et al. (2005), and our personal observations accumulated in the study area. We considered the following trophic guilds: insectivores (I); frugivores (F); insectivore-frugivores (IF); granivores $(\mathrm{G})$; nectarivores $(\mathrm{N})$; omnivores $(\mathrm{O})$.

\subsection{Statistical analysis}

To analyze our data eliminating the effect of differences between the capture efficiencies of the mist-netting methods, we calculated species accumulation based on 29 samples of 10 individuals (following the chronological order of captures). Species accumulation curves were calculated analytically using 50 randomizations by the Coleman method (Colwell et al., 2004). We used the estimator Chao 2, which is indicated for samples with high variation, as the one found in our study. Chao 2 also accurately estimates actual richness, even with a small sample size (Colwell and Coddington, 1994). The rarefaction curves and the richness estimators were calculated using the software EstimateS (Colwell, 2005). We tested the data distribution and when data were not homocedastic, we used non-parametrical statistics (following Zar, 1999) with a confidence level of 95\% $(P<0.05)$. To determine whether more individuals of a given species were captured in VM or GL nets, we used Chi-square tests, in the software Statistica 6.0 (Statsoft, 2001). We used the software Systat 11 (Wilkinson, 2004) for Kolmogorov-Smirnov test.

\section{Results}

There was significant difference between the assemblages sampled with the two methods, i.e. GL nets and VM nets (Kolmogorov-Smirnov, $N=47 ; P<0.05$ ). In VM nets $(0-17 \mathrm{~m}), 44$ species were captured, whereas 30 species were captured in conventional nets (0-2.4 m). Only three species were exclusive to the latter. The rarefaction curves differed between the two methods after approximately 50 individuals sampled, and only the GL nets had a stabilizing trend. Considering the 290 individuals sampled, the total estimated species richness of the VM nets was 65 species, which was almost twice that of the GL nets (35).
The estimator values tended to stabilize around 140 and 170 individuals sampled for GL and VM nets, respectively. Among the species whose capture frequencies could be compared between both methods, approximately $20 \%$ differed significantly (Chi-squared test, $P<0.05)$ and consisted mainly of Suboscine passerine species (Table 1).

The captured species richness was higher in the VM nets for all trophic guilds except granivores. Frugivore richness (10) differed the most from the GL nets (four species captured) (Figure 1a). The number of individuals captured per trophic guild differed significantly between GL and VM nets (total Chi-squared $\mathrm{x}_{3}=21.7 ; P<0.001$ - due to the reduced number of granivores and omnivores, they were combined into a single category). When analyzing each guild separately, insectivores were significantly more abundant in the GL nets $\left(\mathrm{x}_{1}{ }_{1}=11.0 ; P<0.001\right)$, whereas frugivores $\left(\mathrm{x}^{2}=4.6\right.$; $P<0.05)$ and nectarivores $\left(\mathrm{x}^{2}=5.0 ; P<0.05\right)$ were captured more frequently in the VM nets (Figure 1b).

\section{Discussion}

Regarding the relative abundances of trophic guilds, our results show that the understory is the forest stratum with the highest frequency of insectivores and a reduced proportion of birds that feed on plants. However, it is
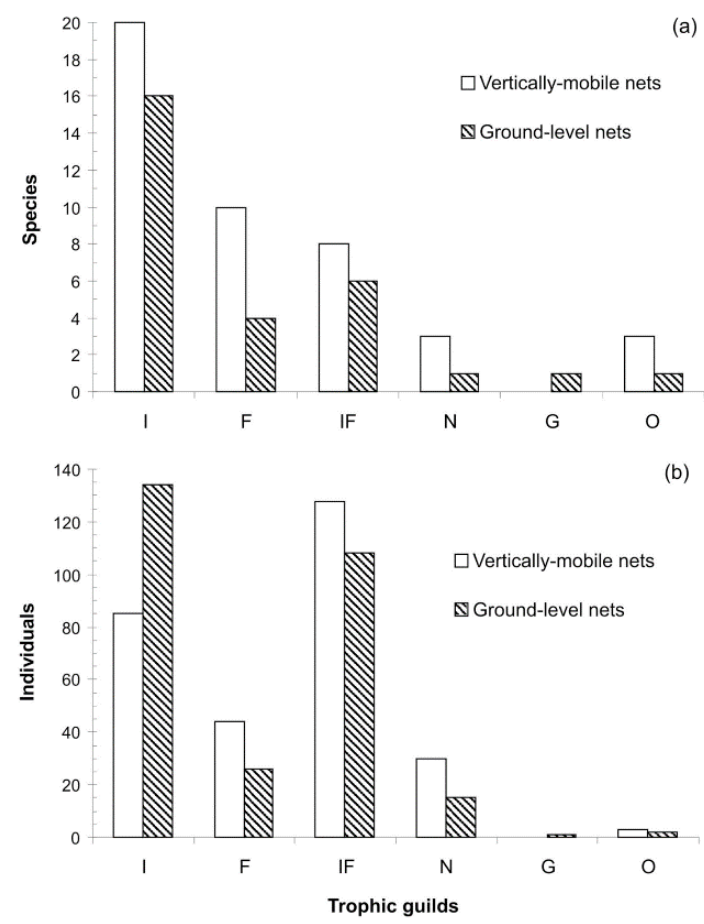

Figure 1. Number of captured bird (a) species and (b) individuals of different trophic guilds using elevated (0-17 m height) and ground-level (0-2.4 m height) nets in an Atlantic Forest area at Ilha Grande, southeastern Brazil. $\mathrm{I}=$ insectivores; $\mathrm{F}=$ frugivores; $\mathrm{IF}=$ insetivore-frugivores; $\mathrm{N}=$ nectarivores; $\mathrm{G}=$ granivores; $\mathrm{O}=$ omnivores $(\mathrm{N}=290$ per net system). 
Table 1. Bird species and abundances by captures with vertically-mobile and ground-level nets in Atlantic Forest at Ilha Grande, southeastern Brazil. Taxonomy follows Remsen et al. (2015).

\begin{tabular}{|c|c|c|c|c|c|}
\hline \multirow[b]{2}{*}{ Species } & \multirow[b]{2}{*}{ English names } & \multicolumn{2}{|c|}{ Capture methods } & \multirow{2}{*}{$\begin{array}{c}\text { Chi-squared } \\
\text { test* } \\
\text { df }=1\end{array}$} & \multirow{2}{*}{$\begin{array}{l}\text { Trophic } \\
\text { guilds }\end{array}$} \\
\hline & & $\begin{array}{l}\text { Vertically- } \\
\text { mobile nets }\end{array}$ & $\begin{array}{l}\text { Ground- } \\
\text { level nets }\end{array}$ & & \\
\hline $\begin{array}{l}\text { Geotrygon montana (Linnaeus, } \\
1758 \text { ) }\end{array}$ & Ruddy Quail-Dove & 0 & 1 & & $\mathrm{~F}$ \\
\hline $\begin{array}{l}\text { Leptotila rufaxilla Bonaparte, } \\
1855\end{array}$ & Gray-fronted Dove & 3 & 2 & ns & $\mathrm{F}$ \\
\hline Florisuga fusca (Vieillot, 1817) & Black Jacobin & 1 & 0 & & $\mathrm{~N}$ \\
\hline $\begin{array}{l}\text { Thalurania glaucopis (Gmelin, } \\
\text { 1788) }\end{array}$ & Violet-capped Woodnymph & 28 & 15 & $\begin{array}{l}\mathrm{X}^{2}=3.9 \\
P<0.05\end{array}$ & $\mathrm{~N}$ \\
\hline $\begin{array}{l}\text { Amazilia versicolor (Vieillot, } \\
\text { 1818) }\end{array}$ & Versicolored Emerald & 1 & 0 & & $\mathrm{~N}$ \\
\hline Trogon viridis Linnaeus, 1766 & Green-backed Trogon & 1 & 0 & & $\mathrm{~F}$ \\
\hline $\begin{array}{l}\text { Baryphthengus ruficapillus } \\
\text { (Vieillot, 1818) }\end{array}$ & Rufous-capped Motmot & 1 & 0 & & $\mathrm{O}$ \\
\hline $\begin{array}{l}\text { Selenidera maculirostris } \\
\text { (Lichtenstein, 1823) }\end{array}$ & Spot-billed Toucanet & 6 & 1 & & $\mathrm{~F}$ \\
\hline $\begin{array}{l}\text { Veniliornis maculifrons (Spix, } \\
\text { 1824) }\end{array}$ & Yellow-eared Woodpecker & 2 & 2 & ns & I \\
\hline $\begin{array}{l}\text { Amazona rhodocorytha } \\
\text { (Salvadori, 1890) }\end{array}$ & Red-browed Parrot & 1 & 0 & & $\mathrm{~F}$ \\
\hline $\begin{array}{l}\text { Pyrrhura frontalis (Vieillot, } \\
\text { 1817) }\end{array}$ & Maroon-bellied Parakeet & 1 & 0 & & $\mathrm{~F}$ \\
\hline Rhopia gularis (Spix, 1825) & Star-throated Antwren & 1 & 9 & $\begin{array}{l}\mathrm{x}^{2}=6.4 \\
P=0.01\end{array}$ & I \\
\hline $\begin{array}{l}\text { Dysithamnus mentalis } \\
\text { (Temminck, 1823) }\end{array}$ & Plain Antvireo & 5 & 15 & $\begin{array}{l}\mathrm{X}^{2}=5.0 \\
P<0.03\end{array}$ & I \\
\hline $\begin{array}{l}\text { Myrmotherula unicolor } \\
\text { (Ménétriès, 1835) }\end{array}$ & Unicolored Antwren & 3 & 2 & ns & I \\
\hline $\begin{array}{l}\text { Hepsilochmus rufimarginatus } \\
\text { Temminck, 1822) }\end{array}$ & Rufous-winged Antwren & 1 & 0 & & I \\
\hline $\begin{array}{l}\text { Drymophila squamata } \\
\text { (Lichtenstein, 1823) }\end{array}$ & Scaled Antbird & 5 & 11 & ns & I \\
\hline $\begin{array}{l}\text { Pyriglena leucoptera (Vieillot, } \\
1818 \text { ) }\end{array}$ & White-shouldered Fire-eye & 2 & 13 & $\begin{array}{l}\mathrm{x}^{2}=8.1 \\
P<0.01\end{array}$ & I \\
\hline $\begin{array}{l}\text { Conopophaga melanops } \\
\text { (Vieillot, 1818) }\end{array}$ & Black-cheeked Gnateater & 8 & 14 & ns & $\mathrm{I}$ \\
\hline $\begin{array}{l}\text { Chamaeza campanisona } \\
\text { (Lichtenstein, 1823) }\end{array}$ & Short-tailed Antthrush & 5 & 8 & ns & I \\
\hline $\begin{array}{l}\text { Sclerurus scansor (Ménétriès, } \\
1835 \text { ) }\end{array}$ & Rufous-breasted Leaftosser & 10 & 14 & ns & I \\
\hline $\begin{array}{l}\text { Dendrocincla turdina } \\
\text { (Lichtenstein, 1820) }\end{array}$ & Plain-winged Woodcreeper & 5 & 16 & $\begin{array}{l}\mathrm{x}^{2}=5.8 \\
P=0.02\end{array}$ & I \\
\hline $\begin{array}{l}\text { Xiphorhynchus fuscus (Vieillot, } \\
\text { 1818) }\end{array}$ & Lesser Woodcreeper & 15 & 18 & ns & I \\
\hline $\begin{array}{l}\text { Cichlocolaptes leucophrys } \\
\text { (Jardine \& Selby, 1830) }\end{array}$ & Pale-browed Treehunter & 1 & 1 & & I \\
\hline $\begin{array}{l}\text { Philydor atricapillus (Wied, } \\
\text { 1821) }\end{array}$ & Black-capped Foliage-gleaner & 10 & 6 & ns & $\mathrm{I}$ \\
\hline Philydor rufum (Vieillot, 1818) & Buff-fronted Foliage-gleaner & 5 & 0 & & I \\
\hline $\begin{array}{l}\text { Anabacerthia lichtensteini } \\
\text { (Cabanis \& Heine, 1859) }\end{array}$ & $\begin{array}{l}\text { Ochre-breasted Foliage- } \\
\text { gleaner }\end{array}$ & 2 & 3 & ns & I \\
\hline Elaenia mesoleuca (Deppe, 1830) & Olivaceous Elaenia & 1 & & & IF \\
\hline
\end{tabular}

Trophic guilds: $\mathrm{F}=$ frugivores; $\mathrm{G}=$ granivores; $\mathrm{I}=$ insetivores; $\mathrm{IF}=$ insetivore-frugivores; $\mathrm{N}=$ nectarivores; $\mathrm{O}=$ omnivores.

$*$ ns= non-significant differences $(\mathrm{p}>0.05)$. 
Table 1. Continued...

\begin{tabular}{|c|c|c|c|c|c|}
\hline \multirow[b]{2}{*}{ Species } & \multirow[b]{2}{*}{ English names } & \multicolumn{2}{|c|}{ Capture methods } & \multirow{2}{*}{$\begin{array}{c}\text { Chi-squared } \\
\text { test* } \\
\text { df }=1\end{array}$} & \multirow[b]{2}{*}{$\begin{array}{l}\text { Trophic } \\
\text { guilds }\end{array}$} \\
\hline & & $\begin{array}{l}\text { Vertically- } \\
\text { mobile nets }\end{array}$ & $\begin{array}{l}\text { Ground- } \\
\text { level nets }\end{array}$ & & \\
\hline $\begin{array}{l}\text { Mionectes rufiventris Cabanis, } \\
1846\end{array}$ & Gray-hooded Flycatcher & 13 & 13 & ns & IF \\
\hline $\begin{array}{l}\text { Leptopogon amaurocephalus } \\
\text { Tschudi, } 1846\end{array}$ & Sepia-capped Flycatcher & 5 & 0 & & IF \\
\hline $\begin{array}{l}\text { Platyrinchus mystaceus Vieillot, } \\
1818\end{array}$ & White-throated Spadebill & 1 & 0 & & I \\
\hline $\begin{array}{l}\text { Lathrotriccus euleri (Cabanis, } \\
\text { 1868) }\end{array}$ & Euler's Flycatcher & 1 & 0 & & I \\
\hline Attila rufus (Vieillot, 1819) & Gray-hooded Attila & 2 & 1 & & I \\
\hline Lipaugus lanioides (Lesson, 1844) & Cinnamon-vented Piha & 1 & 0 & & $\mathrm{~F}$ \\
\hline $\begin{array}{l}\text { Chiroxiphia caudata (Shaw \& } \\
\text { Nodder, 1793) }\end{array}$ & Swallow-tailed Manakin & 24 & 22 & ns & $\mathrm{F}$ \\
\hline $\begin{array}{l}\text { Cyclarhis gujanensis (Gmelin, } \\
\text { 1789) }\end{array}$ & Rufous-browed Peppershrike & 1 & 0 & & I \\
\hline $\begin{array}{l}\text { Cantorchilus longirostris } \\
\text { (Vieillot, 1819) }\end{array}$ & Long-billed Wren & 0 & 1 & & I \\
\hline Turdus flavipes Vieillot, 1818 & Yellow-legged Thrush & 4 & 1 & & IF \\
\hline Turdus albicollis Vieillot, 1818 & White-necked Thrush & 64 & 50 & ns & IF \\
\hline $\begin{array}{l}\text { Trichothraupis melanops } \\
\text { (Vieillot, 1818) }\end{array}$ & Black-goggled Tanager & 36 & 36 & ns & IF \\
\hline $\begin{array}{l}\text { Thraupis cyanoptera (Vieillot, } \\
\text { 1817) }\end{array}$ & Azure-shouldered Tanager & 4 & 0 & & IF \\
\hline $\begin{array}{l}\text { Tangara cyanocephala (Statius } \\
\text { Muller, 1776) }\end{array}$ & Red-necked Tanager & 1 & 0 & & $\mathrm{~F}$ \\
\hline Dacnis cayana (Linnaeus, 1766) & Blue Dacnis & 1 & 0 & & $\mathrm{O}$ \\
\hline $\begin{array}{l}\text { Haplospiza unicolor Cabanis, } \\
1851\end{array}$ & Uniform Finch & 0 & 2 & & G \\
\hline $\begin{array}{l}\text { Coereba flaveola (Linnaeus, } \\
\text { 1758) }\end{array}$ & Bananaquit & 1 & 2 & & $\mathrm{O}$ \\
\hline $\begin{array}{l}\text { Saltator similis d'Orbigny \& } \\
\text { Lafresnaye, } 1837\end{array}$ & Green-winged Saltator & 3 & 6 & ns & IF \\
\hline $\begin{array}{l}\text { Basileuterus culicivorus (Deppe, } \\
\text { 1830) }\end{array}$ & Golden-crowned Warbler & 2 & 2 & ns & IF \\
\hline $\begin{array}{l}\text { Euphonia violacea (Linnaeus, } \\
\text { 1758) }\end{array}$ & Violaceous Euphonia & 2 & 0 & & $\mathrm{~F}$ \\
\hline
\end{tabular}

Trophic guilds: $\mathrm{F}=$ frugivores; $\mathrm{G}=$ granivores; $\mathrm{I}=$ insetivores; $\mathrm{IF}=$ insetivore-frugivores; $\mathrm{N}=$ nectarivores; $\mathrm{O}=$ omnivores.

$* \mathrm{~ns}=$ non-significant differences $(\mathrm{p}>0.05)$.

important to note that even splitting the capture effort over different strata we recorded ground-dwelling species. Except for Ruddy Quail-Dove (Geotrygon montana), all ground-foraging species captured in GL nets were also captured in VM nets. Uniform Finch (Haplospiza unicolor) was captured exclusively in GL nets, but it has irregular temporal and spatial distribution (Alves, 2007) and it was recorded probably due to the higher temporal amplitude of the data from GL nets in our study.

Seventeen species were captured exclusively in the VM nets. Taking into account that there were only 17 of these systems in the study grid (much less than the 30 points of GL nets), and that the captures occurred during a short period of three months, the higher richness from VM nets is mainly due to its reduced bias and its high efficacy for sampling bird diversity among the strata. We believe this bias of GL nets is strongest in undisturbed forest habitats like our study site at Ilha Grande since the foraging breadths for bird species are narrower in primary forests (Ramachandran and Ganesh, 2012). Nevertheless, mist-netting strictly at ground fails to sample the actual diversity of bird assemblages, even in secondary growth habitats with low-stratified vegetation (Bonter et al., 2008).

Violet-capped Woodnymph (Thalurania glaucopis) was the only hummingbird species captured in GL nets during the sampling period, but it was significantly more abundant 
in the VM nets, where Black Jacobin (Florisuga fusca) and Versicolored Emerald (Amazilia versicolor) were also captured. These data show that captures restricted to the lower strata of Atlantic Forest areas tend to underestimate hummingbirds richness and abundance.

Six frugivorous species were captured exclusively in VM nets, but they were represented by only one or two individuals. This may indicate that fruits are more available close to the canopy and that populations of frugivorous birds are less dense. Since fruits are relatively variable in space and time (Willis, 1979), frugivorous birds need large home ranges (Loiselle and Blake, 1991). Many insectivorous species are rare and vulnerable to extinction (Goerck, 1997), which results from certain restrictions on habitat and behavior. For example, army-ant-follower insectivores, such as White-shouldered Fire-eye (Pyriglena leucoptera), are restricted to well-preserved forests, but may be locally abundant. Apart from this species, three others were captured with a frequency significantly higher in the GL nets. These species were all insectivorous suboscines (Plain Antvireo Dysithamnus mentalis, Star-throated Antwren Rhopia gularis and Plain-winged Woodcreeper Dendrocincla turdina), which suggests that this group may be generally overestimated in studies of bird captures with conventional GL nets. Comparing data from bird census in Honduras using ground- and canopy-based methods, Anderson (2009) stated that ground methods underestimated richness and abundance of many canopy birds, including nectarivores, obligate frugivores and seed dispersers.

During our study at Ilha Grande, GL nets had higher capture efficiency, but some of the individuals belonged to a few species that are highly frequent in the lower stratum of the forest and tend to be relatively oversampled. When it is not feasible to use VM nets, any other method that allows overlapping at least two nets (sampling up to 4-5 m in height), such as articulated PVC (Meyers and Pardieck, 1993) or even long bamboo poles, would already help make the sampling less selective towards terricolous species.

The specificity of our primary data from three months of captures in the present study serves as an example. During 419 net-hours carried out at level one (0-2.4 m height), we captured 20 species. When this same effort (419 net-hours) was split between the levels one and two (0-4.8 m height), we captured 27 species (M. B. Vecchi, unpubl. data). In short, the use of nets at only two different height levels may be enough to increase the richness of the captured species by over one third.

Our study in the Atlantic Forest reinforces that different sampling methodologies used at the same location may result in extremely distinct diagnoses of avifauna, both qualitatively and quantitatively. With the use of GL nets (0-2.4 $\mathrm{m}$ height), we recorded less than $2 / 3$ of the richness of the captured species when we sampled different forest strata (0-17 $\mathrm{m}$ height). Considering the total species richness estimated by Chao 2 for VM nets (65), the number of species empirically recorded with GL nets (30) is less than half. Additionally, GL nets tended to under or overestimate the relative abundance of at least $1 / 4$ of the captured species, favoring insectivorous Suboscine species. Therefore, the dissemination of capture studies with the method we used or similar systems of elevated mist nets is a feasible and necessary way to more accurately represent the bird fauna in Atlantic Forest areas.

\section{Acknowledgements}

We thank all members of the Lab. Ecologia de Aves of UERJ, who helped in various field and laboratory stages. Centro de Estudos Ambientais e Desenvolvimento Sustentável (CEADS/UERJ) helped with all logistical support. RHF Macedo, HG Bergallo, CEL Esbérard, CFD Rocha and AJ Piratelli provided many contributions in earlier versions of this manuscript, and Emily J Toriani-Moura with English review. ICMBio/CEMAVE provided permits for captures and banding (3036/1 and 1237/4, respectively). This study is part of MBV's thesis at the Programa de Pós-Graduação em Biologia/UERJ, where the first author received a $\mathrm{PhD}$ fellowship (CAPES). MASA received a CNPq (proc. 308792/2009-2) and FAPERJ grant (proc. E-26/102837/2012), MBV received a Pos-doc fellowship (FAPERJ - proc. E-26/100.162/2008) while writing this paper.

\section{References}

ALHO, CJR., SCHNEIDER, M. and VASCONCELLOS, LAS., 2002. Degree of threat to the biological diversity in the Ilha Grande State Park (RJ) and guidelines for conservation. Brazilian Journal of Biology = Revista Brasileira de Biologia, vol. 62, no. 3, p. 375-385. http://dx.doi.org/10.1590/S1519-69842002000300001. PMid:12530174.

ALVES, MAS., 2001. Estudos de ecologia de aves na Ilha Grande, Rio de Janeiro. In ALBUQUERQUE, JLB., CÂNDIDO JUNIOR, JF., STRAUBE, FC. and ROOS, AL. (Eds). Ornitologia e conservação - da ciência às estratégias. Tubarão: Editora Unisul. p. 61-68.

ALVES, MAS., 2007. Sistemas de migrações de aves em ambientes terrestres no Brasil: exemplos, lacunas e propostas para o avanço do conhecimento. Revista Brasileira de Ornitologia, vol. 15, no. 2, p. 243-250.

ALVES, MAS. and VECCHI, MB., 2009. Birds, Ilha Grande, state of Rio de Janeiro, Southeastern Brazil. Check List, vol. 5, no. 2 , p. $300-313$.

ANDERSON, DL., 2009. Ground versus canopy methods for the study of birds in tropical forest canopies: implications for ecology and conservation. The Condor, vol. 111, no. 2, p. 226-237. http:// dx.doi.org/10.1525/cond.2009.090032.

ANDERSON, DL. and NAKA, LN., 2011. Comparative structure and organization of canopy bird assemblages in Honduras and Brazil. The Condor, vol. 113, no. 1, p. 7-23. http://dx.doi. org/10.1525/cond.2011.100007.

ARIZAGA, J., DEÁN, JI., VILCHES, A., ALONSO, D. and MENDIBURU, A., 2011. Monitoring communities of small birds: a comparison between mist-netting and counting. Bird Study, vol. 58, no. 3, p. 291-301. http://dx.doi.org/10.1080/000 63657.2011.586415. 
BELL, HL., 1982. A bird community of New Guinean lowland rainforest. 3. Vertical distribution of the avifauna. Emmu, vol. 82, no. 3, p. 143-162. http://dx.doi.org/10.1071/MU9820143.

BERNARD, E., 2001. Vertical stratification of bat communities in primary forests of Central Amazon, Brazil. Journal of Tropical Ecology, vol. 17, no. 1, p. 115-126. http://dx.doi.org/10.1017/ S0266467401001079.

BONTER, DN., BROOKS, EW. and DONOVAN, TM., 2008. What are we missing with only ground-level mist nets? Using elevated nets at a migration stopover site. Journal of Field Ornithology, vol. 79 , no. 3, p. 314-320. http://dx.doi.org/10.1111/j.15579263.2008.00179.x

BOURICIUS, B., STOKES, AE. and SCHULTZ, BB., 2002. The canopy platform: an economical but limited access technique. In MITCHELL, AW., SECOY, K. and JACKSON, T. (Eds). Global canopy handbook: techniques of access and study in the forest roof. Oxford: Global Canopy Programme. p. 29-32.

COLWELL, RK., 2005. EstimateS: statistical estimation of species richness and shared species from samples. Software version 8.2.0. Available from: <http://purl.oclc.org/estimates>. Access in: 17 Dec 2013.

COLWELL, RK. and CODDINGTON, JA., 1994. Estimating terrestrial biodiversity through extrapolation. Philosophical Transactions of the Royal Society of London. Series B, Biological Sciences, vol. 345, no. 1311, p. 101-118. http://dx.doi.org/10.1098/ rstb.1994.0091. PMid:7972351.

COLWELL, RK., MAO, CX. and CHANG, J., 2004. Interpolating, extrapolating, and comparing incidence-based species accumulation curves. Ecology, vol. 85, no. 10, p. 2717-2727. http://dx.doi. org/10.1890/03-0557.

DEJONGHE, JF. and CORNUET, JF., 1983. A system of easily manipulated, elevated mist nets. Journal of Field Ornithology, vol. 54 , no. 1, p. $84-88$.

DERLINDATI, EJ. and CAZIANI, SM., 2005. Using canopy and understory mist nets and point counts to study bird assemblages in Chaco forests. The Wilson Bulletin, vol. 117, no. 1, p. 92-99. http://dx.doi.org/10.1676/03-063.

DUNN, EH. and RALPH, CJ., 2004. Use of mist nets as a tool for bird populations monitoring. Studies in Avian Biology, vol. 29, p. 1-6.

DURÃES, R. and MARINI, MÂ., 2005. A quantitative assessment of bird diets in the Brazilian Atlantic forest, with recommendations for future diet studies. Ornitologia Neotropical, vol. 16, no. 1, p. $65-83$.

FITZGERALD, BM., ROBERTSON, HA. and WHITAKER, AH., 1989. Vertical distribution of birds mist-netted in a mixed lowland forest in New Zealand. Notornis, vol. 36, no. 4, p. 311-321.

GOERCK, JM., 1997. Patterns of rarity in the birds of the Atlantic Forest of Brazil. Conservation Biology, vol. 11, no. 1, p. 112-118. http://dx.doi.org/10.1046/j.1523-1739.1997.95314.x.

GREENBERG, R., 1981. The abundance and seasonality of forest canopy birds on Barro Colorado Island, Panama. Biotropica, vol. 13, no. 4, p. 241-251. http://dx.doi.org/10.2307/2387802.

GREENLAW, JS. and SWINEBROAD, J., 1967. A method for constructing and erecting aerial-nets in a forest. Bird-Banding, vol. 38, no. 2, p. 114-119. http://dx.doi.org/10.2307/4511357.
HUMPHREY, PS., BRIDGE, D. and LOVEJOY, TE., 1968. A technique for mist-netting in the forest canopy. Bird-Banding, vol. 39, no. 1, p. 43-50. http://dx.doi.org/10.2307/4511439.

JAYSON, EA., and MATHEW, DN., 2003. Vertical stratification and its relation to foliage in tropical forest birds in Western Ghats (India). Acta Ornithologica, vol. 38, no. 2, p. 111-116. http:// dx.doi.org/10.3161/068.038.0207.

KARR, JR., 1981. Surveying birds with mist nets. Studies in Avian Biology, vol. 6, p. 62-67.

LOISELLE, BA., 1988. Bird abundance and seasonality in a Costa Rican lowland forest canopy. The Condor, vol. 90, no. 4, p. 761-772. http://dx.doi.org/10.2307/1368833.

LOISELLE, BA. and BLAKE, JG., 1991. Temporal variation in birds and fruits along an elevational gradient in Costa Rica. Ecology, vol. 72 , no. 1, p. 180-193. http://dx.doi.org/10.2307/1938913.

LOPES, LE., FERNANDES, AM. and MARINI, MÂ., 2005. Diet of some Atlantic Forest birds. Ararajuba, vol. 13, no. 1, p. 95-103.

LOW, SH., 1957. Banding with mist nets. Bird-Banding, vol. 28 , no. 3, p. 115-128.

MACARTHUR, RH. and MACARTHUR, AT., 1974. On the use of mist nets for population studies of birds. Proceedings of the National Academy of Sciences of the United States of America, vol. 71, no. 8, p. 3230-3233. http://dx.doi.org/10.1073/pnas.71.8.3230. PMid:16578721

MEYERS, JM. and PARDIECK, KL., 1993. Evaluation of three elevated mist net systems for sampling birds. Journal of Field Ornithology, vol. 64, no. 2, p. 270-277.

MOOJEN, J., CARVALHO, JCM. and LOPES, HS., 1941. Observações sobre o conteúdo gástrico das aves brasileiras. Memorias do Instituto Oswaldo Cruz, vol. 36, no. 3, p. 405-444. http://dx.doi.org/10.1590/S0074-02761941000300016.

MUNN, CA., 1991. Tropical canopy netting and shooting lines over tall trees. Journal of Field Ornithology, vol. 62, no. 4, p. 454-463.

NAKA, LN., 2004. Structure and organization of canopy bird assemblages in Central Amazonia. The Auk, vol. 121, no. 1, p. 88-102. http://dx.doi.org/10.1642/0004-8038(2004)121[0088:SA OOCB]2.0.CO;2.

ORIANS, GH., 1969. The number of bird species in some tropical forests. Ecology, vol. 50, no. 5, p. 783-801. http://dx.doi. org/10.2307/1933692

PEARSON, DL., 1971. Vertical stratification of birds in a tropical dry forest. The Condor, vol. 73, no. 1, p. 46-55. http://dx.doi. org $/ 10.2307 / 1366123$.

PEARSON, DL., 1975. The relation of foliage complexity to ecological diversity of three Amazonian bird communities. The Condor, vol. 77, no. 4, p. 453-466. http://dx.doi.org/10.2307/1366092.

PEÑA-FOXON, M. and DÍAZ, IA., 2012. An inexpensive portable platform for wildlife observation in the forest canopy. Bosque (Valdivia), vol. 33, no. 2, p. 233-236. http://dx.doi.org/10.4067/ S0717-92002012000200014.

RALPH, CJ., GEUPEL, GR., PYLE, P., MARTIN, TE. and DESANTE, DF., 1993. Handbook of field methods for monitoring landbirds. Albany: United States Department of Agriculture. 46 p. General Technical Report. PSW-GTR-144.

RAMACHANDRAN, V. and GANESH, T., 2012. Habitat structure and its effects on bird assemblages in the Kalakad-Mundanthurai 
Tiger Reserve, India. Journal of the Bombay Natural History Society, vol. 109, no. 1-2, p. 87-95.

RAMACHANDRAN, V. and GANESH, T., 2013. Birds of the "Canopy": historical perspective, current trends, and future directions. In LOWMAN, M., DEVY, S. and GANESH, T. (Eds.). Treetops at risk. New York: Springer. p. 201-208.

RAHMAN, MA., 2002. Using mist-nets on canopy walkways in Malaysia to study canopy avifauna. The Raffles Bulletin of Zoology, vol. 50, no. 2, p. 499-506.

REMSEN, JV., ARETA, JI., CADENA, CD., JARAMILLO, A., NORES, M., PACHECO, JF., PÉREZ-EMÁN, J., ROBBINS, MB., STILES, FG., STOTZ, DF. and ZIMMER, KJ., 2015. A classification of the bird species of South America. American Ornithologists' Union. Available from: <http://www.museum. lsu.edu/ Remsen/SACCBaseline.html>. Access in: 31 Jul. 2015.

SCHUBART, O., AGUIRRE, AC. and SICK, H., 1965. Contribuição para o conhecimento da alimentação das aves brasileiras. Arquivos de Zoologia de São Paulo, vol. 12, p. 95-249.

SHAW, DC., 2002. Sampling birds in the forest canopy using a canopy crane. In MITCHELL, AW., SECOY, K. and JACKSON, T. (Eds.). Global Canopy handbook: Techniques of access and study in the forest roof. Oxford: Global Canopy Programme. p. 156-159.

SICK, H., 1997. Ornitologia brasileira. Rio de Janeiro: Nova Fronteira. $912 \mathrm{p}$

Statsoft, 2001. STATISTICA (data analysis software system). Tulsa: Statsoft Inc.

STOKES, AE., SCHULTZ, BB., DEGRAAF, RM. and GRIFFIN, CR., 2000. Setting mist nets from platforms in the forest canopy. Journal of Field Ornithology, vol. 71, no. 1, p. 57-65. http:// dx.doi.org/10.1648/0273-8570-71.1.57.

TERBORGH, J., ROBINSON, SK., PARKER III, TA., MUNN, CA. and PIERPOINT, N., 1990. Structure and organization of an Amazonian forest bird community. Ecological Monographs, vol. 60, no. 2, p. 213-238. http://dx.doi.org/10.2307/1943045.

VECCHI, MB., 2007. Assembleia de aves em área de Mata Atlântica pouco perturbada: estratificação vertical na riqueza, na composição de espécies e nas guildas tróficas. Rio de Janeiro: Universidade do Estado do Rio de Janeiro. 98 p. Doctoral thesis in Biology.

WALTHER, BA., 2003. Why canopy access is essential to understand canopy birds: four examples from the Surumoni Crane Project. Ornitologia Neotropical, vol. 15, p. 41-52.

WANG, Y. and FINCH, DM., 2002. Consistency of mist netting and point counts in assessing landbird species richness and relative abundance during migration. The Condor, vol. 104, no. 1, p. 5972. http://dx.doi.org/10.1650/0010-5422(2002)104[0059:COM NAP]2.0.CO;2.

WHITAKER, AH., 1972. An improved mist net rig for use in forests. Bird-Banding, vol. 43, no. 1, p. 1-8. http://dx.doi. org/10.2307/4511820.

WHITMAN, AA., 2004. Use of mist nets for study of Neotropical bird communities. Studies in Avian Biology, vol. 29, p. 161-167.

WILKINSON, L., 2004. SYSTAT: the system for statistics. Evanston: SYSTAT Inc.

WILLIS, EO., 1979. The composition of avian communities in remanescent woodlots in southern Brazil. Papéis Avulsos de Zoologia, vol. 33, no. 1, p. 1-25.

WINKLER, H., 2002. Sampling birds in the canopy. In MITCHELL, AW., SECOY, K. and JACKSON, T. (Eds.). Global Canopy handbook: techniques of access and study in the forest roof. Oxford: Global Canopy Programme. p. 153-155.

ZAR, JH., 1999. Biostatistical analysis. New Jersey: Prentice Hall. 662 p. 
Appendix 1. Description of vertically-mobile net systems

The structure of ropes for supporting VM nets used in the present study was based on the technique used in the Brazilian Amazon described by Humphrey et al. (1968). Although the mechanism is essentially the same, our continuous personal experience with this system in studies at Ilha Grande since 2003 have allowed us to make adjustments that simplified set up, operation and maintenance (Figure 2). In the studied area of Atlantic Forest, we set up 22 systems of VM nets, on which the maximum elevation point varied between 12-20 m. Authors as Humphrey et al. (1968) and Whitaker (1972) considered this kind of sampling system to be proper for canopy studies. We believe that our nets could sample the lower main canopy (sensu Bell, 1982), though there are methods that enable placing mist nets above the medium canopy, attaching it more easily to emergent trees (Munn, 1991).

Each VM net requires the previous installation of a structure of ropes that allows the mist net to be elevated from ground level to the desirable height (similar to the raising of a flag). The system of ropes, in turn, consists of a fixed and a mobile part. The fixed part is a rope horizontally attached between two high trees. Two knots are tied on this horizontal rope, located at approximately $1 \mathrm{~m}$ beyond the length of the net to be used (in the case of the present study, $12 \mathrm{~m}$ ). The mobile part of the system is formed by another extension of rope that passes through aluminum pulleys (the kind used in a clothes-line) attached to the knots made in the fixed rope and next to the ground, just below the upper pulleys. An additional pair of pulleys is placed on one of the sides of the mobile system (one on the fixed rope and the other next to the ground). These pulleys are also crossed by the mobile rope, which is finally tied on one of its ends. This structure enables each end of the mobile system to have a piece of rope that, when pulled, allows the net, which is attached to hangers inserted on these ropes (in our study we used simple plastic carabiners, generally used in bag handles), to be moved up and down by a single person. Compared with the original method by Humphrey et al. (1968), the following modifications were made:

Supporting line - In order to reduce the bending of the net due to wind, a supporting line was incorporated into the system. This element consisted of a nylon thread $(\geq 1.0 \mathrm{~mm})$ that was tied next to the ground on each side of the net and was stretched over the horizontal part of the support rope towards the medium part of the net $(6 \mathrm{~m})$. In this way, when the wind blows, the $12 \mathrm{~m}$ net is supported on one of the sides of the line, which reduces its bending distance by half. The addition of the supporting line significantly reduced the occurrence of friction and interlacement between the mesh and the vegetation (M. B. Vecchi, unpubl. data). This modification allowed the set up of VM nets at a short distance from the background vegetation. The minimal distance between the plane of the $\mathrm{VM}$ net and the background vegetation varied between 0.2 and $2.5 \mathrm{~m}$, and was $0.65 \mathrm{~m}( \pm 0.67)$ on average (M. B. Vecchi, unpubl. data). While studying birds in seven height classes above the ground of a tropical evergreen forest and a moist deciduous forest in southern India, Jayson and Mathew (2003) found significant positive correlation between foliage abundance and species richness and between foliage abundance and numbers of birds visually detected. In fact, considering 12 months of study with 19 points of elevated net (total 105 net-hour

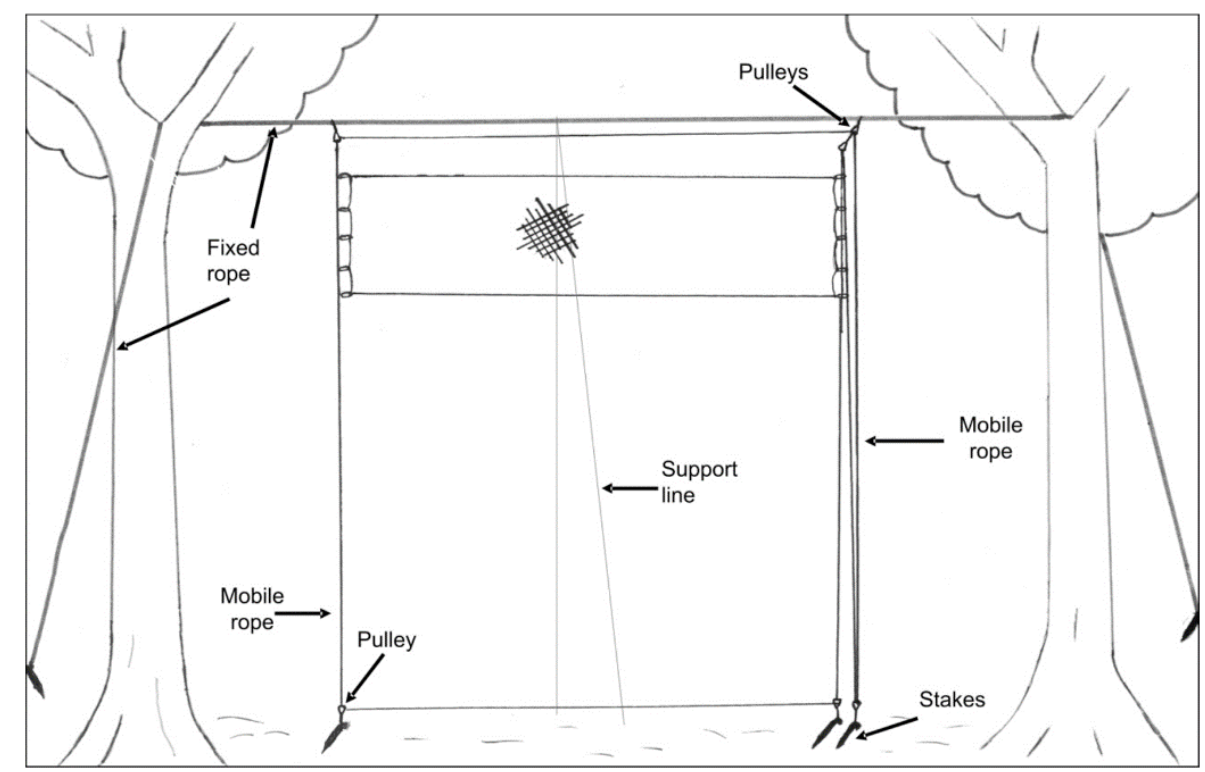

Figure 2. Schematic of an elevated net system in Atlantic Forest area at Ilha Grande, southeastern Brazil. 
per point) in the forest of Ilha Grande, the number of bird species mist-netted was inversely proportional to the distance of the background vegetation, although there was no relationship with the number of captured individuals (Vecchi, 2007). Other studies using elevated net systems recommend the cleaning and removal of all vegetation, from the ground to the height of the supporting ropes of the net, at a distance from 2 to $4 \mathrm{~m}$ of each side of the net plane (Humphrey et al., 1968; Whitaker, 1972). However, Whitaker (1972) observed that the further apart from the background vegetation the nets are, the fewer birds they will capture.

Simplified and low cost set up and maintenance - We used a sling to install the net system from the ground level. All ropes passed through tree forks using nylon threads tied to lead weights that served as guidelines for the thicker ropes. This and others reported methods for the projection of ropes (Greenlaw and Swinebroad, 1967; Munn, 1991) dispense tree climbing techniques (and their relatively expensive equipment) used in the original method. Our rope projection also enabled some branches to be only moved instead of removed. The branches remained tied at less than $1 \mathrm{~m}$ from the net, which is far enough away to avoid branch interlacement in the nets due to wind and increase bird capture success.
Three millimeter braided ropes are already resistant enough, but we recommend ropes thicker than $3.5 \mathrm{~mm}$ because they are more durable. In order to avoid excessive tension on the fixed rope due to the movement of the supporting branches by the wind, we recommend loosening these ropes when not in use (Whitaker, 1972).

Another modification was the removal of what Humphrey et al. (1968) called safety rope, whose original purpose was to bring the structure of fixed ropes down to the ground level for repairs. In the present study, this element was not used and did not compromise system operation. When the mobile ropes were simultaneously attached by hand and pulled, they properly fulfilled this function on all occasions when it was necessary to bring the structure down for repairs. Such adjustments additionally lowered the cost of the original system, which was already relatively cheaper than other methods of bird capture with VM nets (Whitaker, 1972; Stokes et al., 2000; Meyers and Pardieck, 1993; Winkler, 2002).

The low cost of VM net systems allowed us to install those nets at different sites, even without the ease of the conventional nets. A good number of replicates are important to obtain a representative sample of the study area since captured bird composition at similar heights may vary between nearby sites, even in an apparently homogeneous area (Fitzgerald et al., 1989). 